\title{
均質化法を用いたマクロき裂とミクロき裂群間の 弾性相互干渉効果の検討*
}

\author{
中谷彰宏*1, 北川浩*1, 西山英 俊*2 \\ Estimation of Elastic Interaction Effects \\ between Macrocrack-Microcrack Array by \\ Homogenization Method
}

Akihiro NAKATANI, Hiroshi KITAGAWA and Hidetoshi NISHIYAMA

\begin{abstract}
Two-dimensional macrocrack-microcrack array elastic interactions are studied by using homogenization method. The overall elastic moduli of the cracked material are estimated by solving the microscopic problem on the unit cell and they are used in the macroscopic problem. Macrocrack is regarded as a crack in infinite elastic solid, and microcrack array is regarded as locally periodic micro structure with crack, and the periodic and parallel crack array is configured in the macrocrack tip region. It is found that the effects of interaction by changing of the microcrack parameters that are crack length, position, orientation and loading mode, significantly alter stress and stress intensity factor, then effects of amplification and shielding are observed. Especially by microcrack array rotation, effect of shielding that is toughening by microcracking is caused at an angle, under mode I, mode II or combined mode.
\end{abstract}

Key Words: Computational Mechanics, Micromechanics, Finite Element Method, Fracture Mechanics, Stress Intensity Factor, Homogenization Method, Overall Elastic Modulus, Shielding and Amplification Effect

\section{1.はじめに}

セラミックスをはじめとするぜい性材料における破 壊の様式の一つに材料内部に存在する微小き裂と哚く 関わって起こるものがある，そのような場合の破壊の 条件は, マクロき裂とその先端近傍に分布するミクロ き裂群との間の相互干涉によって大きく影響を受けて いると考えられる，従来の研究の多くは，方法論的に， ミクロき裂を離散的に取り扱う方法(1)-(4)と，ミクロ き裂群の存在を損傷や構成関係の変化として捉える方 法(5)(6)とに大別される. 前者は䈗密な解を得られる反 面，扱えるミクロき裂の数に限界があり，後者はき裂 先端場の詳細については知ることが難しいという問題 を有している. 本研究では均質化法(7)を用いることに よって，両者の中間的な評価方法の可能性を探る。

均質化法は枋料内の局所的ミク口構造が周期的に存 在すると仮定した連続体モデルについて全体構造を解 析する手法である。複合材料に代表されるミクロ構造 を有する材料の力学特性評価などに広く用いられてお $り(8)$ ，最近では，非線形問題に対しても定式化がなさ れ(9)，応用が期待されている，本研究では，き裂を有 するユニットセルを用いた均質化弾性定数の評価，お よび，これまで行われているき裂干涉解析との比較に より，均質化法の適用に対する有効性を検討した後, 無

* 掠稿受付 1998 年4 118 U.

*1 开员, 大陑大学大学院 2-1).

*2 ソ二一(㧣) (画985.0842 多賀城市桜木 $3-4 \cdot 1)$
限体中における半無限き裂としてモデル化されたマク 口き裂と, 周期的に無数に並ぶミクロき裂群との干涉 効果, 特にマクロき裂先端の遮蔽効果, 增幅効果につ いて検討する。

\section{2. 解析手法}

2.1 均兵化法 ${ }^{(7)}$ 図 1 に示すように構造物の任 意点近傍で局所的に周期性を持つミクロ構造が存在し ていると仮定し，ミク口構造の実際の大きさを表わす パラメータ $\eta$ とミクロ構造の座標 $\boldsymbol{y}$ を導入する. 構造 物全体を表現する座標 $x$ とミクロ座標 $y$ の間には次の 関係が成り立つ。

$$
y=\frac{x}{\eta}
$$

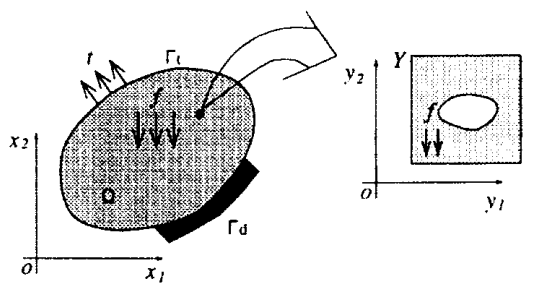

Fig.1 Material with locally periodic microstructure

ここでミクロ構造に依存する変位 $u^{\eta}(x)$ が, 次式のよ うに漸近展開できると仮定する。

$$
u_{i}^{\eta}(\boldsymbol{x})=u_{i}^{(0)}(\boldsymbol{x}, \boldsymbol{y})+\eta u_{i}^{(1)}(\boldsymbol{x}, \boldsymbol{y})+\cdots
$$

図1に示されるような物体内で物体力 $f$ と境界 $\Gamma_{t}$ で表面力 $\boldsymbol{t}$ を受け，ミクロ構造内の空孔内部では荷重 
が作用しない变形問題を仮想仕事の原理を用いて表わ すと次のように書くことができる。

$$
\begin{aligned}
& \int_{\Omega^{\eta}} E_{i j k l}^{\eta} \epsilon_{k l}\left(u^{\eta}\right) \epsilon_{i j}(v) \mathrm{d} \Omega= \\
& \int_{\Omega^{\eta}} f_{i}^{\eta} v_{i} \mathrm{~d} \Omega+\int_{\Gamma_{t}} t_{i} v_{i} \mathrm{~d} \Gamma
\end{aligned}
$$

ここで $E^{\eta}$ は弾性定数テンソル, $v$ は仮想变位, $\epsilon$ は 次のような微小ひずみテンソルである.

$$
\epsilon_{i j}(\boldsymbol{u})=\frac{1}{2}\left(\frac{\partial u_{i}}{\partial x_{j}}+\frac{\partial u_{j}}{\partial x_{i}}\right)
$$

式 (3)に，式(1)の漸近展開式を代入し， $\eta \rightarrow 0$ の極 限を考えると $u_{i}^{(0)}(\boldsymbol{x}, \boldsymbol{y})$ は $x$ のみに依存し， $u_{i}^{(1)}(\boldsymbol{x}, \boldsymbol{y})$ は，式(6)のように表わされる。

$$
\begin{aligned}
& u_{i}^{(0)}(\boldsymbol{x}, \boldsymbol{y})=u_{i}^{(0)}(\boldsymbol{x}) \ldots \ldots \ldots \ldots \ldots \\
& u_{i}^{(1)}(\boldsymbol{x}, \boldsymbol{y})=-\chi_{i}^{k l}(\boldsymbol{x}, \boldsymbol{y}) \epsilon_{k l}\left(\boldsymbol{u}^{(0)}(\boldsymbol{x})\right)
\end{aligned}
$$

ここで $\chi^{k l}$ は，次に示された方程式の解であり，特性変 位とよばれる規格化されたミクロ構造の变位を表わす。

$$
\begin{aligned}
& \int_{Y} E_{i j p q} e_{p q}\left(\chi^{k l}\right) e_{i j}(v(y)) \mathrm{d} Y= \\
& \int_{Y} E_{i j k l} e_{i j}(\boldsymbol{v}(\boldsymbol{y})) \mathrm{d} Y \cdots \cdots
\end{aligned}
$$

この式で $\boldsymbol{e}$ は次に示すミクロ座標 $\boldsymbol{y}$ に関するひずみテ ンソルである。

$$
e_{i j}(v)=\frac{1}{2}\left(\frac{\partial v_{i}}{\partial y_{j}}+\frac{\partial v_{j}}{\partial y_{i}}\right)
$$

これらを式 (3)の仮想仕事の原理式に代入すると

$$
\begin{aligned}
& \int_{\Omega} E_{i j k l}^{H}(\boldsymbol{x}) \epsilon_{k l}\left(\boldsymbol{u}^{(0)}(\boldsymbol{x})\right) \epsilon_{i j}(\boldsymbol{v}(\boldsymbol{x})) \mathrm{d} \Omega \\
& =\int_{\Omega} b_{i}(\boldsymbol{x}) v_{i}(\boldsymbol{x}) \mathrm{d} \Omega+\int_{\Gamma_{t}} t_{i}(\boldsymbol{x}) v_{i}(\boldsymbol{x}) \mathrm{d} \Gamma
\end{aligned}
$$

となる. $E_{i j k l}^{H}(x)$ は，均質化された弾性定数テンソル， $b_{i}(x)$ は，均質化された物体力で，それぞれ次のように 表される。

$$
\begin{aligned}
E_{i j k l}^{H}(\boldsymbol{x}) & =\frac{1}{|Y|} \int_{Y}\left(E_{i j k l}-E_{i j p q} e_{p q}\left(\chi^{k l}\right)\right) \mathrm{d} Y \\
b_{i}(\boldsymbol{x}) & =\frac{1}{|Y|} \int_{Y} f_{i} \mathrm{~d} Y \ldots \ldots \ldots \ldots \ldots \ldots
\end{aligned}
$$

ミクロ構造ユニットセル内の応力分布は, 特性变位 $\chi^{k l}$ を用いて次式で与えられる。

$$
\sigma_{i j}^{0}(x, y)=\left(E_{i j k l}-E_{i j p q} e_{p q}\left(\chi^{k l}\right)\right) \epsilon_{k l}\left(u^{(0)}\right)
$$

\section{$2 \cdot 2$ 直交異方弾性体中のき裂先端応力分布} 裂を有するミクロ構造ユニットセルに対して，式 (10) 加得られる均質化弾性定数は直交異方性を示す。一 般には，式 (9)を満たすマク口場の解 $\boldsymbol{u}^{(0)}$ を得るため のマクロ場の問題は数値的に解かれるが, 本研究では,
マクロ場は均質であると仮定し，解析解を用いること にする。

直交異方弾性体中のモード I，モード II 変形様式に 対する応力分布を与える解析解は，各モードにおける 応力拡大係数を $K_{\mathrm{I}}^{0}, K_{\mathrm{II}}^{0}$ とし，き裂先端を原点とする 極座標系を $(r, \theta)$ とすると，次のように表される(10).

・モードI変形様式

$$
\left.\begin{array}{l}
\left.\sigma_{11}=\frac{K_{\mathrm{I}}^{0}}{\sqrt{2 \pi r}} \operatorname{Re}\left[\frac{\mu_{1} \mu_{2}}{\mu_{1}-\mu_{2}}\left(\mu_{2} f\left(\mu_{2}\right)-\mu_{1} f\left(\mu_{1}\right)\right)\right]\right] \\
\sigma_{22}=\frac{K_{\mathrm{I}}^{0}}{\sqrt{2 \pi r}} \operatorname{Re}\left[\frac{1}{\mu_{1}-\mu_{2}}\left(\mu_{1} f\left(\mu_{2}\right)-\mu_{2} f\left(\mu_{1}\right)\right)\right] \\
\sigma_{12}=\frac{K_{\mathrm{I}}^{0}}{\sqrt{2 \pi r}} \operatorname{Re}\left[\frac{\mu_{1} \mu_{2}}{\mu_{1}-\mu_{2}}\left(f\left(\mu_{1}\right)-f\left(\mu_{2}\right)\right)\right]
\end{array}\right\}
$$

·モード II 変形様式

$$
\left.\begin{array}{l}
\sigma_{11}=\frac{K_{\mathrm{II}}^{0}}{\sqrt{2 \pi r}} \operatorname{Re}\left[\frac{1}{\mu_{1}-\mu_{2}}\left(\mu_{2}^{2} f\left(\mu_{2}\right)-\mu_{1}^{2} f\left(\mu_{1}\right)\right)\right] \\
\sigma_{22}=\frac{K_{\mathrm{II}}^{0}}{\sqrt{2 \pi r}} \operatorname{Re}\left[\frac{1}{\mu_{1}-\mu_{2}}\left(f\left(\mu_{2}\right)-f\left(\mu_{1}\right)\right)\right] \\
\sigma_{12}=\frac{K_{\mathrm{II}}^{0}}{\sqrt{2 \pi r}} \operatorname{Re}\left[\frac{1}{\mu_{1}-\mu_{2}}\left(\mu_{1} f\left(\mu_{1}\right)-\mu_{2} f\left(\mu_{2}\right)\right)\right]
\end{array}\right\}
$$

ここで $f\left(\mu_{i}\right)$ は，次式で定義される.

$$
f\left(\mu_{i}\right)=\frac{1}{\sqrt{\cos \theta+\mu_{i} \sin \theta}}
$$

$\mu_{i}$ は, 次に示すコンプライアンステンソル $C_{i j k l}$ を係 数に持つ特性方程式の共役でない解である.

$$
\begin{array}{r}
C_{1111} \mu^{4}-2 C_{1112} \mu^{3}+\left(2 C_{1122}+C_{1212}\right) \mu^{2} \\
-2 C_{2212} \mu+C_{2222}=0
\end{array}
$$

具体的な解析は以下の手順で行う。まず，ミクロき 裂を持つミクロ構造についてユニットセル上の問題， すなわち，式 (7)を有限要素法を用いて数值的に解き， 式 (10) から得られた均質化弾性定数を用いて，マクロ 問題である直交異方弾性体中のき裂先端応力分布を式 (13)，(14）を用いて解析的に評価し，応力ひずみ関係 を用いてひずみを求めた後, 式 (12) からミク口棈造も 考慮した応力分布を得る。このようにして得られたき 裂先端近傍の応力分布から応力 (外挿) 法(11)により応 力搪大倸数を語価する。

\section{3. 解析モデル}

材料定数として絴弾性係数 $E=206 \mathrm{GPa}$ ，ポアソン 比 $\nu=0.3$ の等方弾性体を考え, 平面ひずみ状態を仮 定することにより 2 次元問題として扱う。まず，均質化 弾性定数の評価值と他の平均化手法による結果との比 較検討するため, 図 2 に示すように，ミクロ構造を代 表するユニットセル内に円孔を有する場合についての 解析を行なう。次に，き裂の干涉モデルについて，マ クロ問題においては半無限き裂先端場を考え，ミクロ 
問題としては図 3 に示すユニットセル内に直線き裂を 持つ場合を考える。一方，マクロ問題では，まず，図 4 に示すように引張り応力 $\sigma$ を負荷したミク口き裂群 のき裂先端の応力拡大係数を求める問題を考え，次に， 半無限き裂先端場を考之，図 5(a)のように，ミクロき 裂がマクロき裂と同一方向を持つ場合について検討し た後，図 5(b)に示すように，ミクロき裂長さ，方向， 負荷モードなどを様々に変化させて解析を行なう。

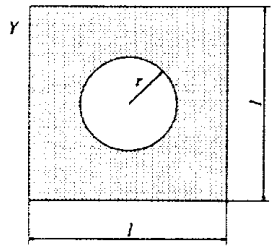

(a) Model

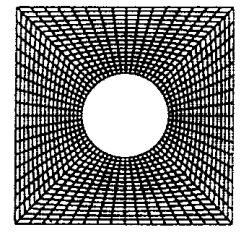

(b) Mesh

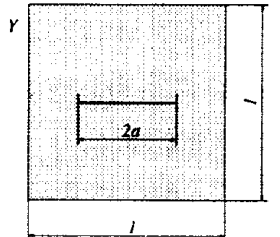

(a) Model

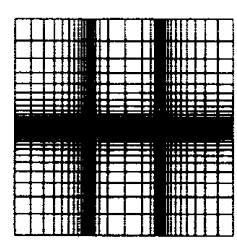

(b) Mesh
Fig.3 Unit cell with microcrack

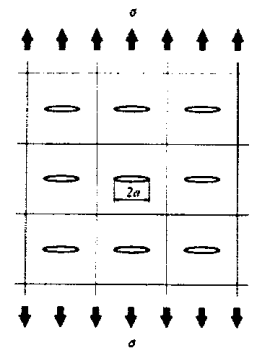

Fig.4 Crack array

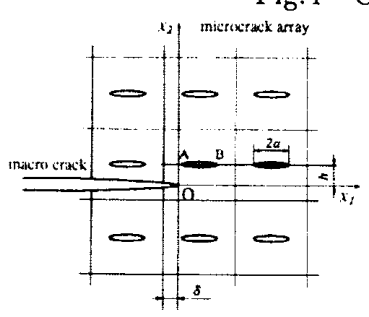

(a) Parallel

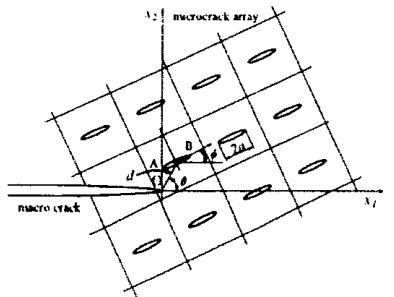

(b) Rotated
Fig.5 Model of macrocrack and microcrack array interaction

\section{4. 解析結果}

4.1 均貿化弾性定数の評価まず，式(10)により 計算される均質化弾性定数について, 従来の様々な平均 化弾性定数を求める方法による結果と比較するために, 図 2 に示すユニットセル内に円孔を持つ場合に対して， 円孔のボイド率 $\left(\pi r^{2}\right)$ を変化させて解析を行なう. 得 られた均質化された弾性特性について, self-consistent 法および dilute distribution(macrostress, macrostrain prescribed) 法(5)による全体平均弾性特性の解と比較を 行なった結果を図6(a)，(b)，(c)に示す. 均質化法による結 果は，ボイド率が小さいときは, dilute distribution 法 の macrostress, macrostrain prescribed, self-consistent 法の解とよく一致するが, ボイド率が大きい場合, 均 質化法による結果と他の方法による結果の差は璔大す る。また, dilute distribution 法により得られる全体平 均弾性係数は上下限解を示すとされるが, 図 6(a), (c) 加，均質化弾性定数はその dilute distribution 法の macrostress prescribed と macrostrain prescribed のほ ほ中間に位置していることがわかる。

次に, 図 3 に示すユニットセル内のミクロき裂の長 さ $2 a$ の変化に対して得られた解析結果を図 7 示す.

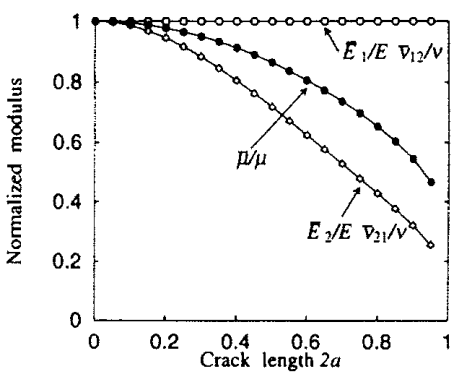

Fig.7 Relation between homogenized modulus and crack length

図 7 は, 均質化弾性定数から得られるミク口き裂に 平行方向, 垂直方向に対する縦弾性係数 $\bar{E}_{1}, \bar{E}_{2}$, ポア ソン比 $\bar{\nu}_{12}, \bar{\nu}_{21}$, 横弾性係数 $\bar{\mu}$ ，それぞれき裂のない 場合の $E, \nu, \mu$ で無次元化して表した結果である。これ らの結果から，ミクロき裂の場合は， $\bar{E}_{1} / E$ と $\bar{\nu}_{12} / \nu の$ 值は等しく，それぞれき裂長さに無関係であり，また， $\bar{E}_{2} / E$ と $\bar{\nu}_{21} / \nu$ の值も等しく,これらと $\bar{\mu} / \mu$ は, それ ぞれミクロき裂長さの増加とともに減少し，0に近づく

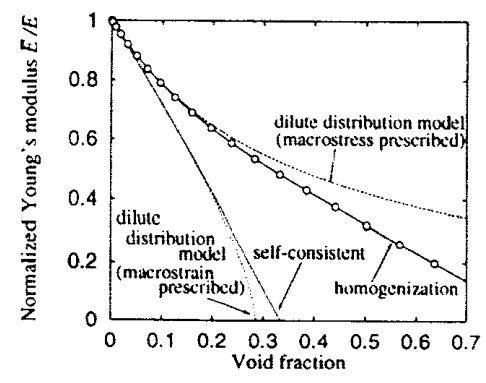

(a)Young's modulus

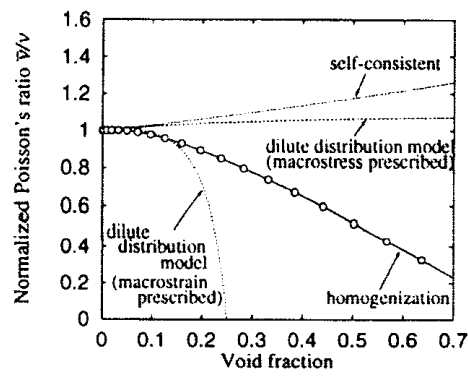

(b) Poisson's ratio

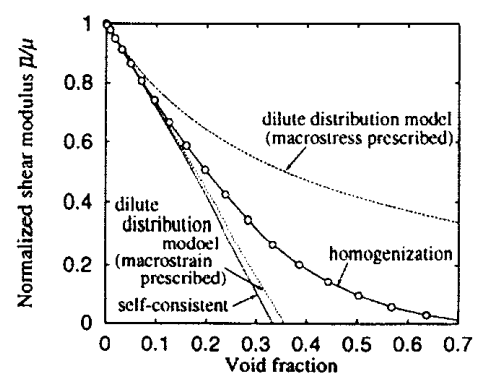

(c) Shear modulus

Fig.6 Relation between homogenized elastic properties and void fraction 
傾向があることがわかる。また，き裂長さに関係なく $\bar{E}_{2} / E=\bar{\nu}_{21} / \nu$ が得られるのは, 2 次元直交異方弾性定 数マトリックスの対称性から得られる $\nu_{21} / E_{2}=\nu_{12} / E_{1}$ が満たされているためである。

\section{$4 \cdot 2$ ミクロき裂群の干涉効果＼cjkstart図 4 に示すよう} に $x_{2}$ 方向に引張り応力 $\sigma$ を負荷したミクロき裂群に ついて得られたミクロき裂先端の応力拡大係数を図 8 に示す。ここで，無限体中で引張りを受ける長さ $2 a(a$ は $\eta$ を 1 として無次元化した値)の単体のき裂に対して 得られる応力拡大係数 $K_{\mathrm{I}}^{0}=\sigma \sqrt{\pi a}$ を用いて無次元化 して示している。

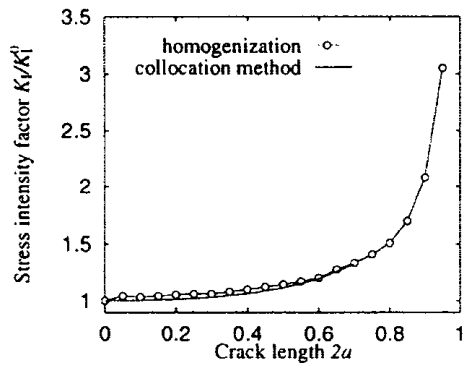

Fig.8 Stress intensity factor by microcrack array interaction

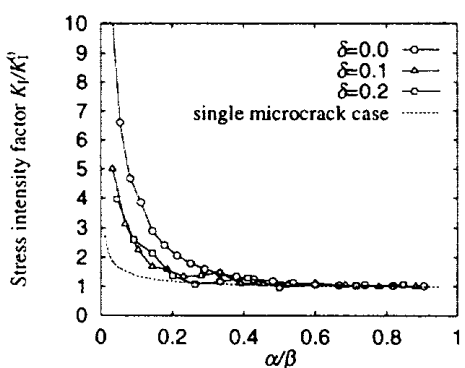

(a) At macrocrack tip (O)

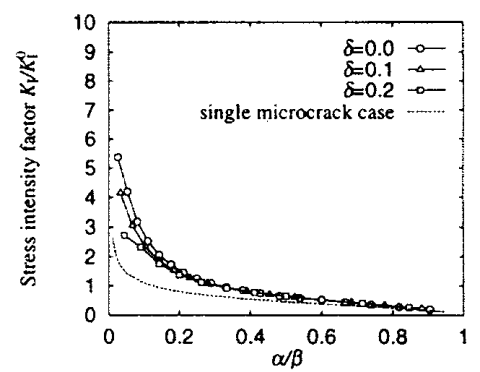

(b) At microcrack tip (A)
図8では，比較のために，選点法(11)による結果を破 線で示している，均質化法に基づく結果は，選点法に よる解よりもやや高めに評価されているものの，よい 一致を示している。このような二重周期配列のき裂群 に対する応力拡大係数評価に対しては，精度では解析 的方法 (12) が優れていると考えられるが，均質化法を用 いることによっても簡便にある程度で評価が可能であ ることがわかる。

4.3 マクロき裂とミクロき裂群との干涉効果 4.3.1 同一の方向の場合図 5(a)に示すように, 長 さ $2 a$ のミクロき裂がマク口き裂と同一方向を持ち，そ のうちの一列が同一線上に並ぶ場合の干涉効果につい て解析する。図5(a)において，マクロき裂先端と最も 近いユニットセルの位置関係を表すパラメータ $h$ と $\delta$ は, $\eta$ を 1 として無次元化している. $h=0.0, \delta=0.0,0.1,0.2$ について，マクロき裂先端 (原点)および，ミクロき裂 先端 (A 点, B 点) 近傍の応力場から評価される応力拡 大係数 $K_{\mathrm{I}}(\mathrm{O}), K_{\mathrm{I}}(\mathrm{A}), K_{\mathrm{I}}(\mathrm{B})$ を式 (13) における $K_{\mathrm{I}}^{0}$ に より無次元化してそれぞれ図 9(a), (b), (c) に示してい る。ここで， $\alpha, \beta$ は，それぞれ， $\mathrm{A}$ 点， $\mathrm{B}$ 点の $x_{1}$ 座標

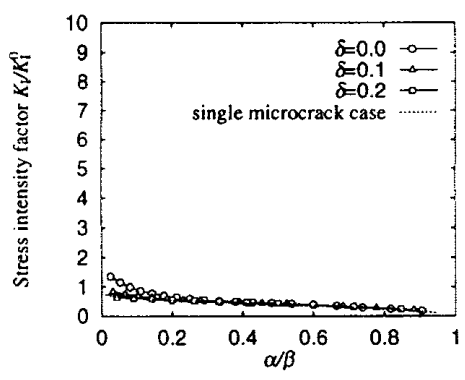

(c) At microcrack tip (B)

Fig.9 Stress intensity factor at cracktip $(h=0.0)$

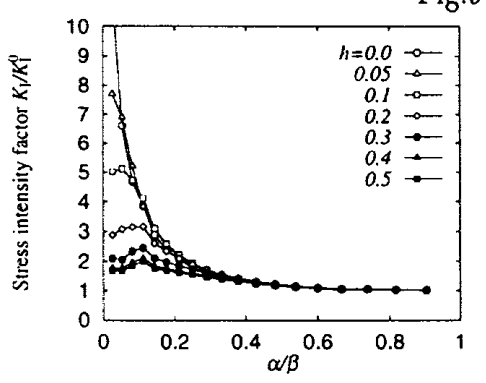

(a) At macrocrack tip (O)

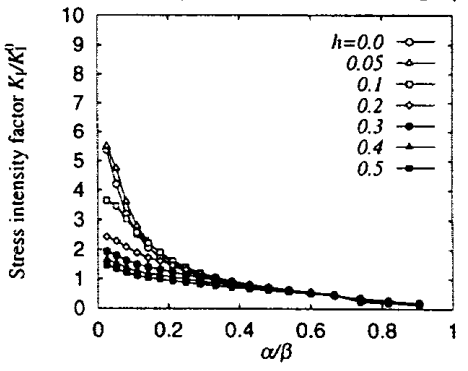

(b) At microcrack tip (A)

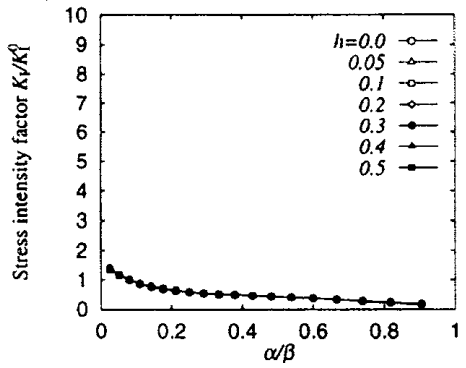

(c) At microcrack tip (B)

Fig.10 Stress intensity factor vs $\alpha / \beta(\delta=0.0)$

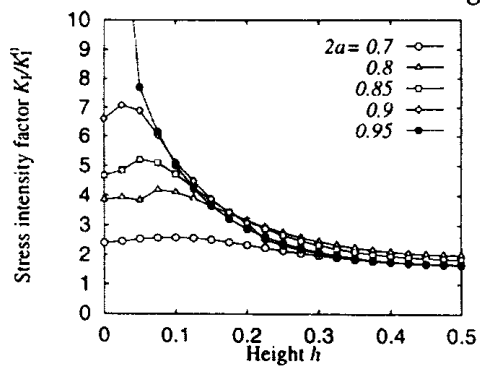

(a) At macrocrack tip (O)

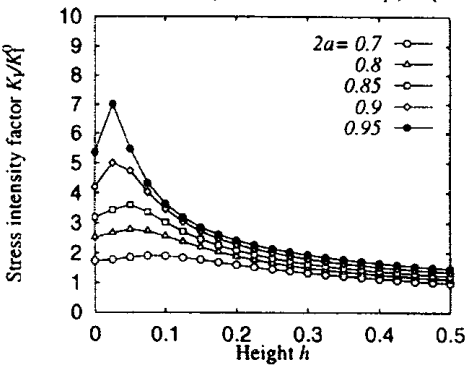

(b) At microcrack tip (A)

Fig.11 Stress intensity factor vs $h(\delta=0.0)$

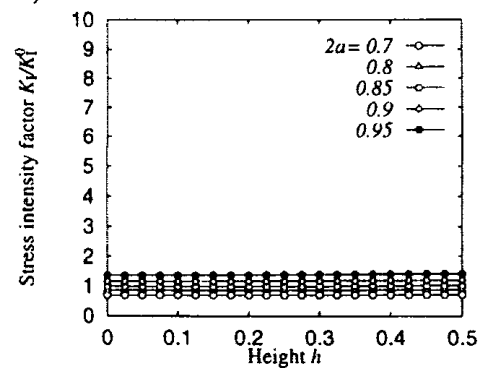

(c) At microcrack tip (B) 
を意味する。これらの結果から，一般に， $K_{\mathrm{I}}(\mathrm{O})>$ $K_{\mathrm{I}}(\mathrm{A})>K_{\mathrm{I}}(\mathrm{B})$ の関係があることがわかる。また，図

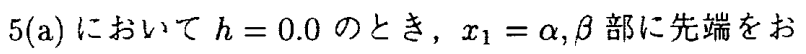
く単一のミクロき裂が存在する場合の解析解(1)(2)を図 中に破線で示している。これらの結果の比較からある 程度 $\alpha / \beta$ が 1 に近い，または， $\delta$ が大きい場合には，本 解析で得られた結果は，マクロき裂とき裂先端近傍の 単一のミクロき裂との相互作用に対する解に近づくこ とがわかる，一方， $\alpha / \beta$ が小さくると，特に $K_{\mathrm{I}}(\mathrm{O})$,

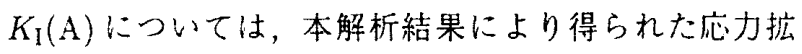
大係数の值は単一のミクロき裂との相互作用に対する 解に比べて顕著に大きくなり，また，同し $\alpha / \beta$ の值に

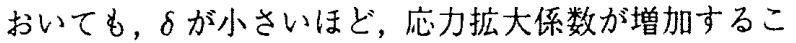
とがわかる。放小さいとミクロき裂間の間隔が狭くな り，ミクロき裂どうしの相互作用が大きくなる。つま り, ミクロき裂どうしの相互作用が大きい程, ミクロ き裂群とマクロき裂との相互作用も大きいことがわか る. $K_{\mathrm{I}}(\mathrm{B})$ に対しても同様な傾向が見られる。図 10(a), (b), (c) および, 図 11(a), (b), (c) は, 図 5(a) に示すマ クロき裂線上に平行なミクロき裂群について $\delta=0.0$ として， $h$ を変化させた場合に得られた $K_{\mathrm{I}}(\mathrm{O}), K_{\mathrm{I}}(\mathrm{A})$ の解析結果を示す。この結果から， $K_{\mathrm{I}}(\mathrm{O}), K_{\mathrm{I}}(\mathrm{A})$ は, $0<h<0.1$ の位置で最大值を示し， $h>0.09$ における $K_{1}(0)$ は， $\alpha / \beta \simeq 0.1$ で最大值を示すという結果が得

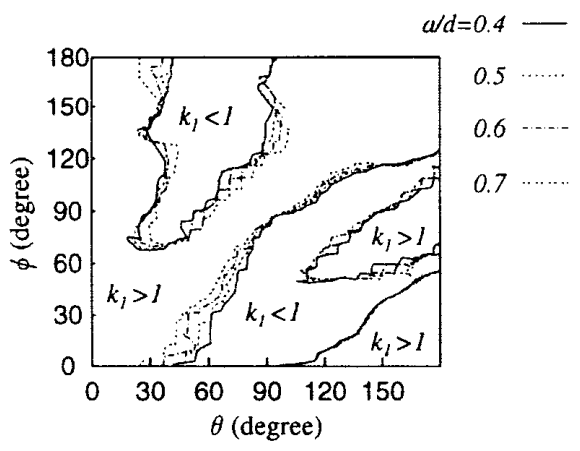

(a) Contour

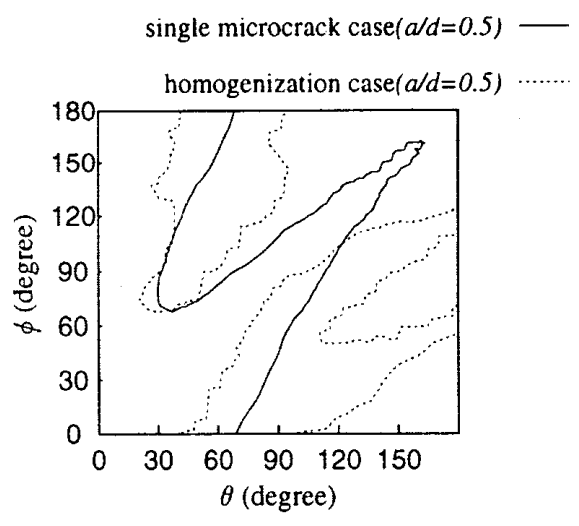

(b) $a / d=0.5$

Fig.12 $k_{1}=1$ contour under mode $I$

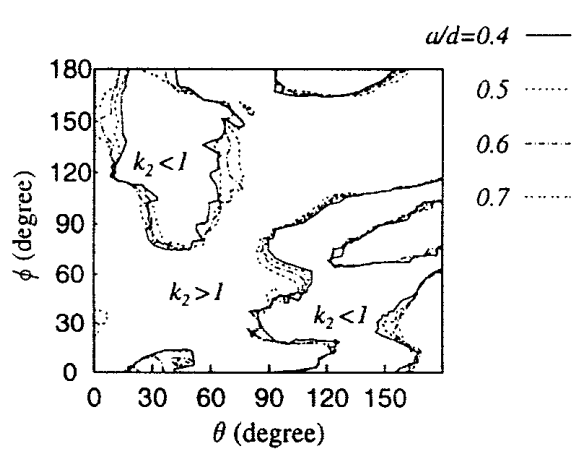

(a) Contour

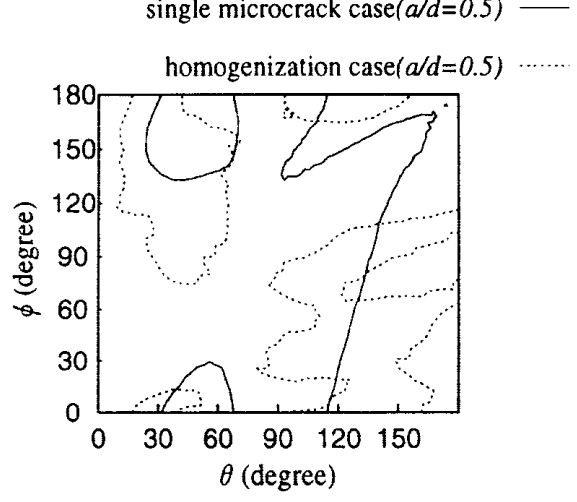

(b) $a / d=0.5$

Fig.13 $k_{2}=1$ contour under mode II

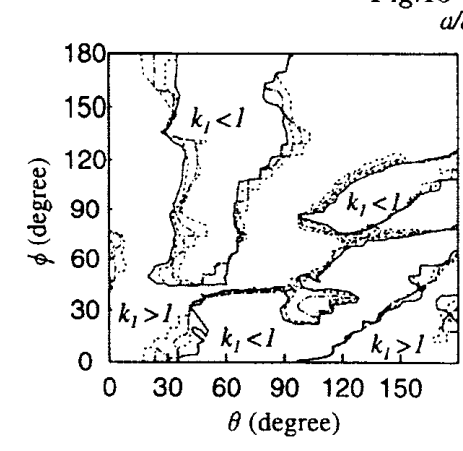

(a) $k_{1}=1$

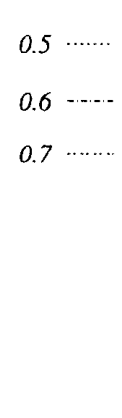

Fith

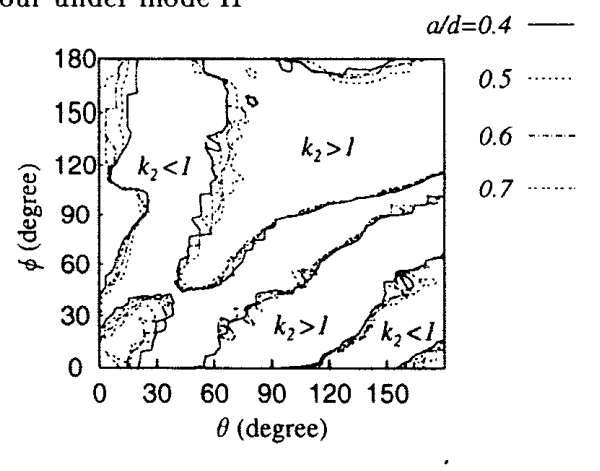

(b) $k_{2}=1$ 


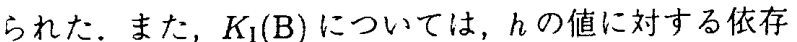
性は見られないが， $\alpha / \beta$ れ，小さくなると， $K_{\mathrm{I}}(\mathrm{B})$ 大き くなる.このことから，B点の応力搪大係数について は，マクロき裂との相互干渉の影響は小さく，むしろ ミクロき裂どうしの相互干渉による影響が大きく現わ れていると考えられる。

4.3.2 回転した方向の場合図5(b)のように, マクロき裂とミクロき裂群が角度 て，ミクロき裂長さ，ミクロき裂群の方向, 負荷モ一 ドを変化させることによる影響を解析する。

図12(a)，13(a)は，それぞれモードI，モードIIの単 独モードのもとでマクロき裂先端の遮蔽一增幅の遷移 境界を示す $k_{1}=K_{\mathrm{I}} / K_{\mathrm{I}}^{0}=1, k_{2}=K_{\mathrm{II}} / K_{\mathrm{II}}^{0}=1$ をミク 口き裂長さ $a / d(d=0.5$ で一定) を変化させて得られた 結果を示している。また，図 14(a)，(b)は，混合モ一 ド $\left(K_{\mathrm{II}}^{0} / K_{\mathrm{I}}^{0}=1.0\right)$ のもとでの $k_{1}=K_{\mathrm{I}} / K_{\mathrm{I}}^{0}=1, k_{2}=$ $K_{\mathrm{II}} / K_{\mathrm{II}}^{0}=1$ をミク口き裂長さを変化させて得られた 結果である。

図 12(b)，13(b) は， $a / d=0.5$ の場合について，モー ド I，モード II の単独モード変形のもとでのマクロき 裂先端に単一のミク口き裂が存在する場合に扔ける $k_{1}=1, k_{2}=1$ の解(3)(4) と，均質化法を用いた本解析 から得られた結果を比較して示している。

これらの結果より，マクロき裂先端において遮蔽お よび增幅効果を示す領域が存在することが確認できる. $k=1$ の境界線はミク口き裂長さ $a / d$ には，ほとんど 影響を受けず，また， $\phi=\theta$ の直線の近傍では，増幅 効果が現れていることがわかる。また，図12(b)，13(b) で，単一なミク口き裂が存在する場合と比較すると両 者は $\theta<90(\mathrm{deg}) に お い て ，$ 類似した傾向が見られる.

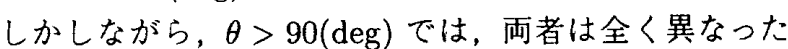
傾向を示していることがわかる。これは， $\theta$ の増加に 伴って，注目して回転させているミクロき裂によるマ クロき裂への影響が小さくなり，ミクロ構造の周期性 より，注目しているユニットセルに隣接するユニット 七ルのミクロき裂がマクロき裂に近づき，影響を与え るために起こる現象であると考えられる。このような 現象は，ミク口き裂の群としての効果だけでなく，均 質化法によるモデル化の際の仮定に起因する近似誤差 などの効果も含まれている可能性があり，今後，この 方法の適用範囲についてより詳細な検討が必要である と考えられる。

\section{5.おわりに}

本論文では，均質化法における均質化弾性定数の解 析と，ミク口き裂間の相互作用，および，マクロき裂 とミクロき裂群との干涉効果について検討を行った結 果以下の結論を得た。
(1)ミク口構造として円孔を考えた場合の均質化弾性定 数の評価では，干涉効果が大きい場合に他の解析的 な平均化手法では, 方法間で結果の差が大きくなり 精度よい解を得ることが困難な場合に対しても，均 質化法を用いることにより，簡便で適切な解を得る ことができる可能性を示した。

（2）ミクロき裂群どうしの渉解析では，選点法による 解との比較から局所的な応力拡大係数が均質化法を 用いることによって簡便，かつ，精度良く評価でき ることを示した。

（3）マクロき裂とミクロき裂群との干涉解析では，ミク 口き裂どうしの相互作用が小さい場合に，均質化法 により得られた結果は, マクロき裂と単一のミクロ き裂との相互作用に対する従来の解と良く一致する ことが確認できた。

(4)ミクロき裂どうしの相互作用が大きい場合には，ミ クロき裂群とマクロき裂との相互作用が単一のミク 口き裂の場合に比べて一般に大きくなり，ミクロき 裂の集まりとしての効果が, 単一のものとは異なっ ていることが確認できた。

結論の (4)に関連して, ミクロき裂の集まりとマク 口き裂との干渉効果以外に，均質化法によるモデル化 の際に導入される仮定に起因する䛊差も含んでいる可 能性が無視できないと考えられる。ここでは検討でき なかったが，他の手法による結果との詳細な比較検討 を通じて，適用範囲などを明らかにすることが今後の 課題である。ささらに，今後，ここで示した方法の発展 によってミクロき裂の合体などを考慮したき裂進展問 題などへの応用が期待できると考えられる.

\section{文献}

(1) Rubinstein,A., Int. J. Frac., 27(1985), 113.

(2) Rose,L.R.F., J. Am. Ceram. Soc., 69(1986), 212.

(3) Wang,X.-M., Gao,S., \& Chen,Y.-H., Int. J. Solids. Structures, 33(1996), 4051.

(4) Gong,S.X. \& Meguid,S.A., Int.J.Mech.Sci, 34(1992), 993.

(5) Nemat-Nasser,S. \& Hori,M., Micromechanics:overall properties of heterogeneous materials, (1993), 95105 ,North-Holland.

(6) Hutchinson,J.W., Acta Metall., 35(1987), 1605.

(7) Guedes,J. \& Kikuchi,N., Com. Meth. Appl. Mech. Engg., 83(1990), 143.

（8）たとえば，高野·座古・大西，材料， 45(1996)，163， 野口・清水，第 41 回材研連前刷集 (1997)，34 など.

（9）寺田·削·㐘池，機論 A, 61-590(1995)，2199-2205.

(10) Sih,G.C., Paris,GP.C., \& Irwin,G.R., Int. J. Frac. Mech., 3(1965), 189-203.

（11）石田 誠, き裂の弾性解析と応力拡大係数, (1976), 116-131,199-200, 培風館.

（12）たとえば，井川秀信・石田 誠，機構論，96-10B(1996), $25-26$. 